\title{
Does ocean acidification induce an upward flux of marine aggregates?
}

\author{
X. Mari \\ UR 103 (IRD), Centre IRD de Nouméa, BP A5, 98848 Nouméa cedex, New Caledonia
}

Received: 17 March 2008 - Published in Biogeosciences Discuss.: 15 April 2008

Revised: 12 June 2008 - Accepted: 30 June 2008 - Published: 23 July 2008

\begin{abstract}
The absorption of anthropogenic atmospheric carbon dioxide $\left(\mathrm{CO}_{2}\right)$ by the ocean provokes its acidification. This acidification may alter several oceanic processes, including the export of biogenic carbon from the upper layer of the ocean, hence providing a feedback on rising atmospheric carbon concentrations. The effect of seawater acidification on transparent exopolymeric particles (TEP) driven aggregation and sedimentation processes were investigated by studying the interactions between latex beads and TEP precursors collected in the lagoon of New Caledonia. A suspension of TEP and beads was prepared and the formation of mixed aggregates was monitored as a function of $\mathrm{pH}$ under increasing turbulence intensities. The $\mathrm{pH}$ was controlled by addition of sulfuric acid. Aggregation and sedimentation processes driven by TEP were drastically reduced when the $\mathrm{pH}$ of seawater decreases within the expected limits imposed by increased anthropogenic $\mathrm{CO}_{2}$ emissions. In addition to the diminution of TEP sticking properties, the diminution of seawater $\mathrm{pH}$ led to a significant increase of the TEP pool, most likely due to swollen structures. A diminution of seawater $\mathrm{pH}$ by 0.2 units or more led to a stop or a reversal of the downward flux of particles. If applicable to oceanic conditions, the sedimentation of marine aggregates may slow down or even stop as the $\mathrm{pH}$ decreases, and the vertical flux of organic carbon may reverse. This would enhance both rising atmospheric carbon and ocean acidification.
\end{abstract}

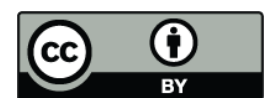

Correspondence to: X. Mari

(xavier.mari@noumea.ird.nc)

\section{Introduction}

Photosynthesis within the euphotic layer is the process by which organic carbon is produced from dissolved inorganic carbon (DIC), thus favoring the drawdown of atmospheric $\mathrm{CO}_{2}$ towards the oceans. The export of primary production from the surface to the deep ocean is a key component of the ocean carbon cycle. This carbon export - often referred to as the biological carbon pump (Volk and Hoffert, 1985) - is responsible for maintaining a vertical gradient of dissolved inorganic carbon (DIC) and thus, a constant drawdown of $\mathrm{CO}_{2}$ on geological time scales (Sarmiento and Siegenthaler, 1992). In such a scheme, the ocean is assumed to play a role in regulating fossil fuel $\mathrm{CO}_{2}$ accumulation by exporting a part of the excess organic carbon produced, provided the DIC fixed during photosynthesis sinks out of the euphotic zone and is buried in sediments.

Therefore, the ocean plays a buffering role for atmospheric carbon concentration, with about half of the anthropogenic $\mathrm{CO}_{2}$ released since pre-industrial times now stored in the ocean (Sabine et al., 2004; Feely et al., 2004). One of the consequences of the continuous uptake of atmospheric $\mathrm{CO}_{2}$ by the ocean is the reduction in seawater $\mathrm{pH}$ (Caldeira and Wickett, 2003), which may decrease by 0.8 to 1.4 units over the next 300 years (Caldeira and Wickett, 2005). While the effects of ocean acidification on carbonate fixing marine organisms received increasing attention in the past decade (Gattuso et al., 1998; Riebesell et al., 2000; Langdon et al., 2003; Orr et al., 2005; Gazeau et al., 2007), the consequences of ocean acidification on the efficiency of the biological carbon pump for regulating atmospheric $\mathrm{CO}_{2}$ emissions are still widely unknown.

Amongst the mechanisms controlling the vertical export of organic carbon, the formation of marine snow aggregates is one of the most important (Shanks and Trent, 1980; Smetacek, 1985; Fowler and Knauer, 1986; Asper et al., 1992; Jackson and Burd, 1998). By determining the

Published by Copernicus Publications on behalf of the European Geosciences Union. 
abundance and sinking characteristics of marine aggregates, aggregation controls vertical export of large particles (Fowler and Knauer, 1986; Asper et al., 1992; Jackson and Burd 1998), of picoplankton cells (Richardson and Jackson, 2007), and of dissolved organic carbon (Engel et al., 2004) - materials ultimately stemming from primary production. The abundance and sinking characteristics of aggregates depend on the rate at which particles collide, and on the probability of adhesion upon collision (i.e., stickiness). While collision rate is controlled by the concentration and size of particles, and by fluid dynamics, adhesion depends upon the sticking properties of particles (Jackson 1990). Particle stickiness proved to play a key role in controlling aggregation and sedimentation (Boyd et al., 2005; Jackson et al., 2005). For example, model simulations predict that an increase of particle stickiness by one order of magnitude (i.e., from 0.1 to 1 ) decreases the critical concentration for algal aggregation by one order of magnitude (Boyd et al., 2005). As a result, an increase of particle stickiness would increase sinking rates and reduce the concentration of particles in the upper ocean (Boyd et al., 2005). While the formation of aggregates is largely controlled by the sticking properties of particles, sedimentation of aggregates depends upon their density. Therefore, the efficiency of the biological pump to adsorb the excess organic carbon produced is ultimately linked to the abundance and density of aggregates.

Transparent exopolymeric particles (TEP) (Alldredge et al., 1993) play a central role in aggregation and sedimentation processes by promoting aggregation (Passow et al., 2001), and by regulating sinking characteristics of aggregates via alteration of their density (Azetsu-Scott and Passow, 2004). The role of TEP as a regulating factor of aggregate formation is two-fold: (1) they increase the concentration of particles and, thus, collision frequency, and (2) they increase particle stickiness and, thus, coagulation efficiency. TEP stickiness, which is higher than that of any other particles, is linked to the presence of a high fraction of acid polysaccharides, which allow them to form cation bridges and hydrogen bonds (Passow, 2002). Therefore, variations of environmental conditions potentially affecting the surface charge distribution and the conformation of TEP, such as $\mathrm{pH}$, may alter their sticking properties (Passow, 2002). Finally, owing to their low density (Azetsu-Scott and Passow, 2004), the relative contribution of TEP to marine aggregates determines the excess density of aggregates and, thus, their fate in the water column. As an example, an aggregate composed of a large proportion of TEP will remain suspended in the water column or even move upward (Azetsu-Scott and Passow, 2004; Mari et al., 2007).

To test how ocean acidification might influence the biological pump and thus the carbon balance, I investigated the effects of $\mathrm{pH}$ variations on the physico-chemical processes of aggregation and sedimentation by conducting a $\mathrm{pH}$ perturbation study with seawater collected in the Southwest lagoon of New Caledonia. This study consisted of a two-step exper- iment. First, cell-free but TEP-precursors-containing seawater was mixed with inert beads, and the interactions between TEP and beads were monitored as a function of $\mathrm{pH}$ under increasing turbulence conditions. This approach allows studying the effect of $\mathrm{pH}$ variations on aggregation, using a simplified marine system composed of naturally occurring TEP and artificial beads. Second, after monitoring the effects of $\mathrm{pH}$ on aggregation processes, the samples containing TEP and beads were transferred into settling chambers, and the vertical transport of particles was monitored over time.

\section{Material and Methods}

\subsection{Sampling}

Seawater samples were collected at a $15 \mathrm{~m}$ deep coastal site in the lagoon of New Caledonia ( $\left.22^{\circ} 15^{\prime} 47^{\prime \prime} \mathrm{S} 166^{\circ} 25^{\prime} 55^{\prime \prime} \mathrm{E}\right)$, at $5 \mathrm{~m}$ depth and at weekly intervals during six occasions in August and September 2007 using a 5L Niskin bottle. The characteristics of the water column were constant over the course of the experiment. The lagoon of New Caledonia is a semi-closed, relatively shallow site, surrounded by oligotrophic oceanic water and connected to the ocean by narrow passes through the reef. The concentrations of chlorophyll a, dissolved inorganic nitrogen (nitrate+nitrite $\left(\mathrm{NO}_{\mathrm{x}}\right)$ ) and phosphorus $\left(\mathrm{PO}_{4}^{3-}\right)$ averaged ( \pm s.d.) $\quad 0.48 \pm 0.07 \mu \mathrm{g} \mathrm{L}^{-1}, 0.09 \pm 0.05 \mu \mathrm{mol} \mathrm{L}^{-1}$, $0.07 \pm 0.01 \mu \mathrm{mol} \mathrm{L}^{-1}$, respectively. The temperature averaged ( \pm s.d.) $22.03 \pm 0.17^{\circ} \mathrm{C}$, and the salinity averaged ( \pm s.d.) $35.40 \pm 0.13$.

\subsection{Experimental set-up}

Seawater was filtered at low vacuum pressure $(<15 \mathrm{kPa})$ through $0.2 \mu \mathrm{m}$ polycarbonate filters. The filtrate that contained TEP precursors was put inside two 2-L containers of a mixing device generating small-scale turbulence. One container was used as the control ( $\mathrm{pH}=8.16)$, while $\mathrm{H}_{2} \mathrm{SO}_{4}$ was added in the other to reach a reduction in $\mathrm{pH}$ of $0.2,0.4$, or 0.8 units.

\subsection{Aggregation}

Variations of the sticking properties of TEP as a function of $\mathrm{pH}$ were studied largely following the method of Mari and Robert (2008). After pH adjustment, Polybead Carboxylate microspheres of $6 \mu \mathrm{m}$ diameter (Polysciences, Inc., initial concentration $=0.025 \mathrm{~g} \mathrm{~mL}^{-1}$ for $2.5 \%$ solid volume, density $=1.05 \mathrm{~g} \mathrm{~cm}^{-3}$ ) were added to the filtrate to yield a final concentration of ca. $4000 \mathrm{~mL}^{-1}$. The volume of beads solution added was calculated from the beads solution characteristics described above. In order to avoid clustering, the volume of beads added to each container was diluted in $20 \mathrm{~mL}$ of $0.2-\mu \mathrm{m}$ filtered seawater stemming from the respective treatment and sonicated for $5 \mathrm{~min}$ prior to turbulence production. 
The mixing device is composed of two grids oscillating vertically inside the two 2-L Plexiglas cylindrical containers, and generates small-scale turbulence under the control of a rotor controlling the oscillation frequency (Peters et al., 2002).

The interactions between TEP and beads were monitored at room temperature (room was temperature controlled at $22^{\circ} \mathrm{C}$ ) under increasing turbulence intensities, tuned at the start of three successive $1 \mathrm{~h}$ periods. The frequency of oscillations was set to reach turbulence kinetic energy dissipation rates, $\varepsilon$, of $0.1,1$, and $10 \mathrm{~cm}^{2} \mathrm{~s}^{-3}$, during the first, second, and third hour of the experiment, respectively (Mari and Robert, 2008). Samples were collected every hour (four sampling occasions) in order to determine TEP size spectra and to describe the relationship between TEP and beads.

\subsection{Vertical transport}

After the last sampling in the turbulence chambers, the solutions were transferred in $250-\mathrm{mL}$ tissue culture flasks. For each treatment, four flasks were filled with $200 \mathrm{~mL}$ of solution in order to follow the vertical repartition of particles over time. Sampling was performed every hour for $4 \mathrm{~h}$, each flask being used for a single sampling occasion. In order to monitor the upward and downward flux of particles, $20 \mathrm{~mL}$ of the surface and bottom layers were siphoned from each flask. Since the room was temperature controlled at $22^{\circ} \mathrm{C}$, which corresponds to the seawater temperature, thermal convection was assumed negligible. During the experiments, the flasks were left perfectly still (i.e., turbulence-free) on the bench. Since there is no thermal gradient inside the settling chambers horizontal convection can be considered minimal and thus, although possible horizontal transport and subsequent attachment to the walls is probably not a significant loss factor.

The height of the studied water column was $8.7 \mathrm{~cm}$. In order to avoid disturbing the layering $20 \mathrm{~mL}$ (corresponding to $9 \mathrm{~mm}$ water column) of the surface layer were siphoned using a Pasteur pipette fixed on a stand. The stand was in turn fixed on an elevating platform (Labo-lift). The pipette was slowly immerged to $9 \mathrm{~mm}$ depth under the surface and the top $20 \mathrm{~mL}$ were gently siphoned by gravity into a small glass vial. In order to recover $20 \mathrm{~mL}$ of the bottom layer, the intermediate water column was siphoned off by slowly immerging the pipette, leaving $20 \mathrm{~mL}$ (a seawater column of $9 \mathrm{~mm}$ ) in the bottom of the settling chamber. After sampling, the solutions were immediately filtered to determine the TEP volume concentration and to enumerate the number of beads.

\subsection{TEP and beads determination}

TEP size spectra, the abundance of beads and the relationship between TEP and beads were determined from $5 \mathrm{~mL}$ sub-samples, which were filtered through $0.2-\mu \mathrm{m}$ polycarbonate filters and stained with Alcian Blue (Alldredge et al. 1993). The retained particles were transferred onto a micro- scope slide (Passow and Alldredge, 1994). TEP size spectra and the total abundance of beads were determined for each slide by counting and sizing TEP and by counting beads at 250x magnification using a compound light microscope. The equivalent spherical diameter (ESD; $\mu \mathrm{m}$ ) of individual TEP was calculated by measuring its cross-sectional area with an image-analysis system (ImagePro Plus, MediaCybernetics) and counts were combined and classified into 20 logarithmic size classes (Mari and Burd, 1998). A relationship between TEP size and numbers of attached beads was established for each sample by sizing individual TEP and enumerating its associated beads at $400 \times$ magnification. A minimum of 20 mixed aggregates of TEP-beads were studied for each slide.

\subsection{Ascending and settling velocity}

Instantaneous ascending and descending velocities of TEP and beads, $W\left(\mathrm{~cm} \mathrm{~s}^{-1}\right)$, were calculated from the variations of the concentration of particles in the surface and the bottom layers, using the formula (Azetsu-Scott and Passow, 2004):

$W=\frac{\left(C_{t}-C_{0}\right) V}{A C_{0} t}$

where $C_{t}$ and $C_{0}$ are the volume concentrations of TEP (ppm) or the concentrations of beads $\left(\mathrm{mL}^{-1}\right)$ in the considered layer at time $t$ and $t 0, V$ is the volume of the considered layer $\left(20 \mathrm{~cm}^{-3}\right), A$ is the area of the settling column $\left(22.32 \mathrm{~cm}^{2}\right)$, and $t(s)$ is the time interval between $\mathrm{t}$ and $t 0$. The distribution of particles was assumed homogeneous throughout the flasks at the start of the settling experiment. The vertical transport of TEP by passive diffusion is too slow to account for the changes observed during these short-term experiments and was thus ignored (Azetsu-Scott and Passow, 2004).

\section{Results and discussion}

\subsection{TEP and beads aggregation}

For each turbulence level, the number of TEP-attached beads per unit of TEP volume decreased significantly in the acidified seawater in comparison to the control (Fig. 1). In addition, the fraction of TEP-attached beads decreased independently of the turbulence level from $66 \pm 9 \%$ in the control treatment, to $45 \pm 6 \%, 30 \pm 12 \%$, and $39 \pm 9 \%$ for a reduction in $\mathrm{pH}$ of $0.2,0.4$, and 0.8 units, respectively. Therefore, the decrease of the number of TEP-attached beads per unit of TEP volume subsequent to acidification seems to be caused by a reduction of TEP sticking properties. Since, in the acidified treatments, TEP promote the formation of aggregates with a reduced proportion of dense particles (i.e., the beads), one may expect the density of aggregates to lessen and, thus, their vertical transport toward the bottom to decrease.

At the start of the settling experiments, $10 \%$ of TEP had a diameter $>12.5 \pm 0.7 \mu \mathrm{m},>15.3 \pm 0.6 \mu \mathrm{m},>15.5 \pm 1.8 \mu \mathrm{m}$, 


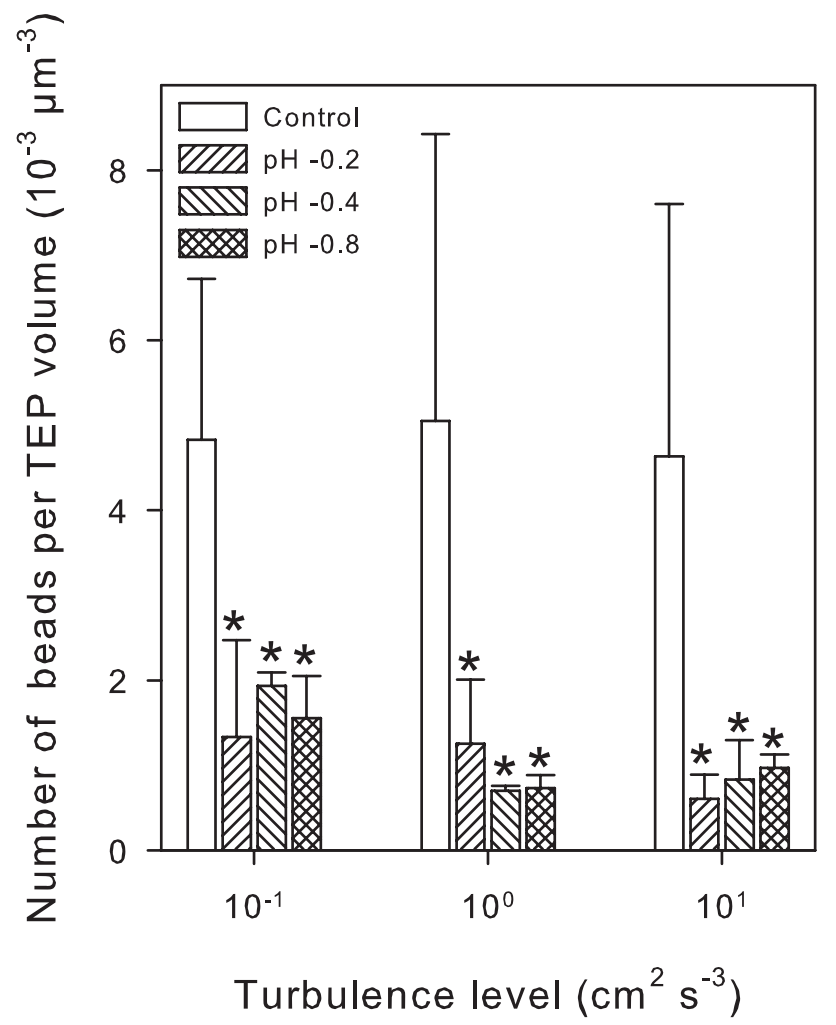

Fig. 1. Variation of the number of TEP-attached beads per unit of TEP volume as a function of $\mathrm{pH}$ under the three successive turbulence regimes. Each value corresponds to the average ( \pm s.d.) of 6 measurements for the control and of 3 measurements for each $\mathrm{pH}$ treatment. The values marked with a cross are significantly different from the control ( $t$-test, $p<0.05)$.

and $>14.5 \pm 1.7 \mu \mathrm{m}$, for the control and for the treatments with a reduction in $\mathrm{pH}$ of $0.2,0.4$, and 0.8 units, respectively (Fig. 2a) thus, indicating a shift to larger size class subsequent to acidification. In addition, the abundance of TEP was higher in the acidified treatments than in the control (Fig. 2b). Due to an increase in both the size and abundance of TEP, their volume concentration at the start of the settling experiments was three-fold higher in the $\mathrm{pH}$ treatments than in the control (Fig. 2b). Since TEP producers were removed by filtration through $0.2 \mu \mathrm{m}$ membranes prior to $\mathrm{pH}$ adjustment and that initial concentrations of TEP precursors were identical in the control and in the acidified seawater, the observed increase cannot be caused by an enhanced production of TEP precursors from phytoplankton or bacteria. Instead, this suggests that the observed increase in the concentration of TEP could be due to a $\mathrm{pH}$-induced alteration of the physico-chemical processes responsible for TEP formation, and not due to a stimulation of the production of TEP precursors by planktonic organisms. As showed by Dogsa et al. (2005), variations of $\mathrm{pH}$ induce a modification of the structure of exopolymeric substances released by bacteria

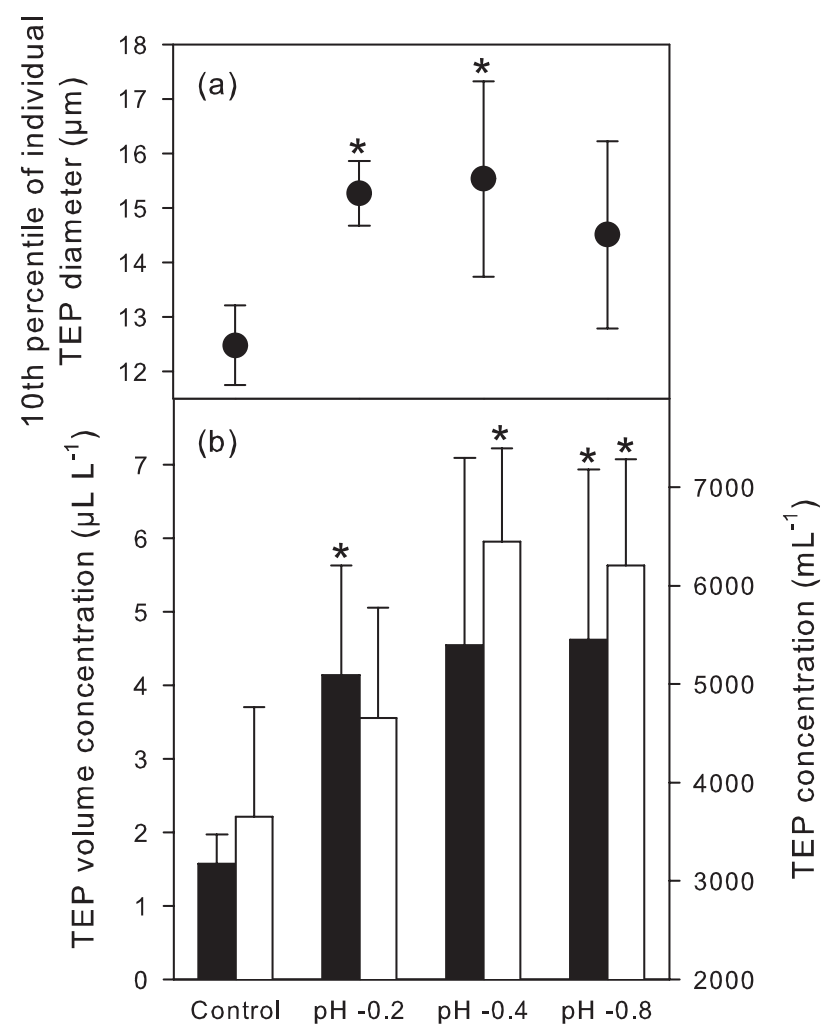

Fig. 2. Effect of $\mathrm{pH}$ variations on: (a) TEP size, as depicted by the 10th percentile of individual TEP volume, and (b) TEP volume concentration (black bars) and abundance (open bars), at the start of the sedimentation experiments. Each value of number and volume concentrations corresponds to the average $( \pm$ s.d.) of 6 measurements for the control and of 3 measurements for each $\mathrm{pH}$ treatment. The values marked with a cross are significantly different from the control ( $t$-test, $p<0.05)$.

and in particular may lead to swollen structures. Accordingly, one may hypothesize that TEP also swell when $\mathrm{pH}$ decreases, which in turn would result in an increase of TEP size independently of aggregation processes. In other words, a reduction of $\mathrm{pH}$ may swell the exopolymeric matrix and lead to an increase in size and, thus, volume concentration, independently of coagulation processes. As a result, the fourfold increase in TEP concentration subsequent to $p \mathrm{CO}_{2}$ enhancement observed during mesocosm experiments (Riebesell et al., 2007; Engel, 2002) could be partly due to a pH-induced modification of TEP structure, rather than to be solely due to an increase of TEP production. However, it is difficult to compare the increase of TEP observed in the present study and in the mesocosm experiments for two reasons. Firstly, because the methods used to determine TEP concentration differed, and secondly TEP producers were present in the mesocosms, thus, increasing TEP production subsequent to $p \mathrm{CO}_{2}$ enhancement. An alternative mechanism that may potentially explain the increase in TEP size when $\mathrm{pH}$ decreases 
is a change the equilibrium between TEP-precursors and TEP in the direction of TEP. However, such a change in the TEPprecursors/TEP balance requires an increase in TEP stickiness, which is contradictory with the observed decrease in the aggregation of TEP with beads, unless the intraspecific (i.e., TEP-TEP) stickiness is enhanced while the interspecific (i.e., TEP-beads) stickiness is reduced.

\subsection{Vertical transport as a function of seawater $\mathrm{pH}$}

In the control treatments, the concentrations of TEP and of beads increased during the first hour of the settling experiment, both in the surface and bottom layers (Fig. 3). This increase in both layers can only occur if TEP and beads moved vertically both upward and downward. The observed decrease of TEP and beads concentrations in the surface layer after the first hour of the experiment suggests that those particles may "escape" the surface sampling after they reached the air-water interface by adhering to the surface microlayer (SML). In addition, when the volume of seawater lowered subsequent to sampling, the SML was mostly likely ruptured and lost via attachment to the inner walls of the chambers. Since the sampling procedure does not seem to recover satisfactorily the TEP and beads that are likely accumulating in the SML, the upward velocity in the control treatments was determined only from changes in TEP and beads concentrations occurring in the surface layer during the first hour. The downward velocity in the control treatments was calculated from changes in particle concentrations occurring in the bottom layer during the first hour.

In the $\mathrm{pH}$ treatments, the concentrations of TEP and of beads always decreased in the bottom layer during the whole experiment (Fig. 3). This decrease in the bottom layer can only occur if both populations of particles moved upward. Accordingly, the concentration of particles should increase in the surface layer. The apparent diminution of TEP and beads concentration in the surface layer, as well as the high variability of the concentration of particles in this layer suggest that the accumulation of particles in the SML may hide the suspected upward flux. Since the concentration of particles in the bottom layer always decreased and that the surface sampling apparently failed to detect the surface accumulation of particles, the upward velocity in the $\mathrm{pH}$ treatments was calculated from changes in TEP and beads concentrations occurring in the bottom layer during the first hour.

As the middle layer was not investigated, it is possible that the particles that moved upward remained in the middle layer and never reached the surface layer. Although the sampling procedure does not allow verifying that this mechanism did not occur, it is considered very unlikely.
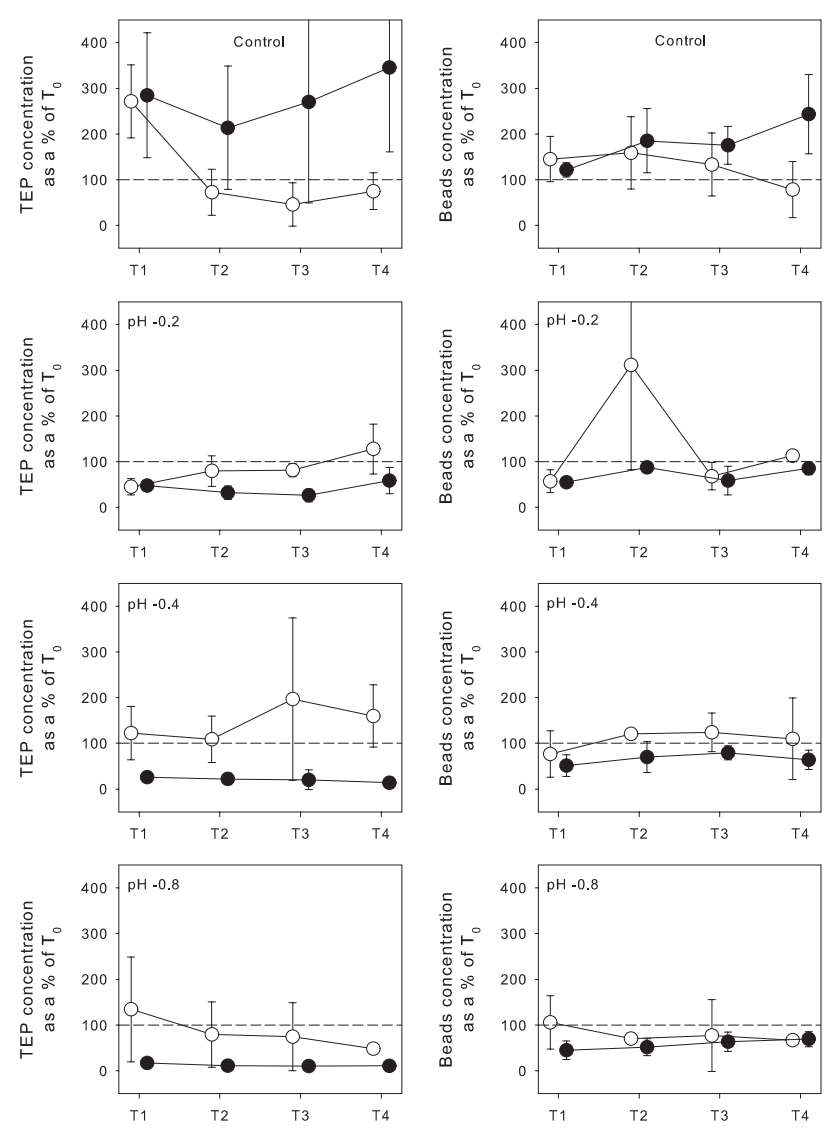

Fig. 3. Variations of TEP and bead concentrations in the surface (open circles) and bottom (black circles) layers as a function of $\mathrm{pH}$ during the settling experiments.

\subsection{Upward and downward particle velocities}

The velocity at which particles moved vertically (i.e., downward and upward) in the settling chambers was calculated from the variation in the concentration of particles at the surface and bottom layers after one hour. Average velocities were calculated from 6 and 3 measurements for the control and $\mathrm{pH}$ treatments, respectively.

In the control, the concentration of TEP increased in both layers. Their settling velocity averaged ( \pm s.d.) $\quad 0.57 \times 10^{-3} \pm 0.43 \times 10^{-3} \mathrm{~cm} \mathrm{~s}^{-1}$, and their ascending velocity averaged ( \pm s.d.) $0.34 \times 10^{-3} \pm 0.16 \times 10^{-3} \mathrm{~cm} \mathrm{~s}^{-1}$. In the acidified seawater, the concentration of TEP in the bottom layer always decreased, and their average ascending velocity increased to $0.40 \times 10^{-3} \pm 0.15 \times 10^{-3}, 0.91 \times 10^{-3} \pm 0.54 \times 10^{-3}$, and $1.80 \times 10^{-3} \pm 0.76 \times 10^{-3} \mathrm{~cm} \mathrm{~s}^{-1}$ for a reduction in $\mathrm{pH}$ of 0.2 , 0.4 , and 0.8 units, respectively. The concentration of beads in the bottom layer of the chambers containing the acidified solutions, decreased to $89 \pm 11 \%, 86 \pm 16 \%$, and $75 \pm 10 \%$ of the initial concentration for a reduction in $\mathrm{pH}$ of $0.2,0.4$, and 0.8 units, respectively. The average ascending velocity of beads 


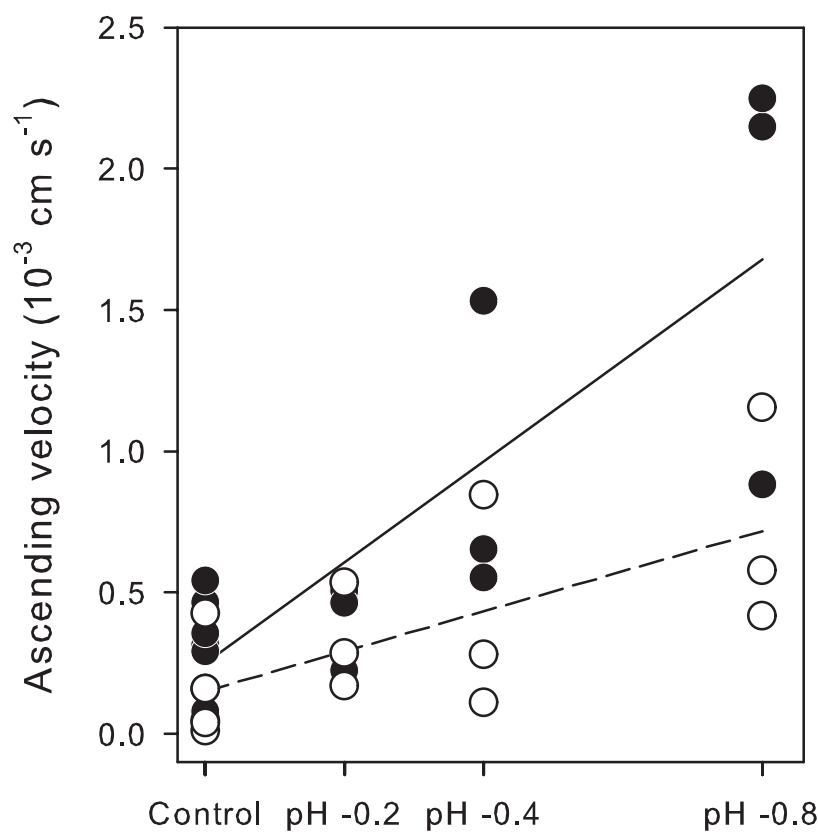

Fig. 4. Effect of $\mathrm{pH}$ variation on ascending velocities of TEP (black circles) and of beads (open circles) in the settling chambers. Relationships between $\mathrm{pH}$ and ascending velocities were determined by correlation and regression analysis using all data $(n=15)$. The ascending velocities increased significantly subsequent to a reduction in $\mathrm{pH}$, for TEP $\left(r^{2}=0.70, p=0.0002, F=26.325\right)$ and beads $\left(r^{2}=0.46, p=0.0054, F=11.097\right)$.

reached $0.33 \times 10^{-3} \pm 0.19 \times 10^{-3}, 0.41 \times 10^{-3} \pm 0.38 \times 10^{-3}$, and $0.72 \times 10^{-3} \pm 0.39 \times 10^{-3} \mathrm{~cm} \mathrm{~s}^{-1}$ for a reduction in $\mathrm{pH}$ of $0.2,0.4$, and 0.8 units, respectively (Fig. 4). On the contrary, the concentration of beads in the bottom layer of the control chambers, reached $258 \pm 78 \%$ of the initial concentration, and the average settling velocity of beads reached $0.19 \times 10^{-3} \pm 0.07 \times 10^{-3} \mathrm{~cm} \mathrm{~s}^{-1}$. This shows that the decrease in $\mathrm{pH}$ stimulated the upward flux of TEP and attached beads.

\subsection{Potential implications for carbon export in the ocean}

Recently it has been shown that an increase of the partial pressure of $\mathrm{CO}_{2}$ could significantly increase the rate of organic carbon removal from the upper layer of the ocean (Riebesell et al., 2007), thus, pleading for biologically-driven feedbacks on rising atmospheric carbon concentration. A suggested pathway for this excess carbon consumption is the settling of organic material linked to enhanced TEP concentration (Riebesell et al., 2007). Conversely, one may also argue that the observed elevated consumption of DIC is indeed associated with higher loss of organic carbon in the water column, but upward rather than downward, in other words into the SML. This alternative pathway is supported by the four-fold increase in the concentration of TEP (Riebesell et al., 2007) and, thus, the likely enhanced contribution of TEP within aggregates composition, which in turn should reduce their density.

Previous studies have shown that TEP could reduce the sinking velocity of marine aggregates by decreasing their density. Azetsu-Scott and Passow (2004) demonstrated that TEP have a density lower than seawater, and that they move upward unless combined with denser particles. In addition, they also demonstrated that TEP can bring attached beads to the surface. During their study, Azetsu-Scott and Passow (2004) used beads with the same density as those in the present study. By studying sinking velocities of large Nitzschia closterium aggregates $(>0.1 \mathrm{~cm})$, Engel and Schartau (1999) proposed that sinking velocity of such aggregates decreased when their specific TEP content increased. Thus, it is clear that TEP can reduce the sinking velocity of marine aggregates depending on the concentration at which they appear inside aggregates.

During a study of the development of a coastal bloom, Azetsu-Scott and Niven (2005) presented further evidence that TEP may indeed promote an upward flux of organic matter. The authors showed that TEP concentrations were consistently higher in the surface layer (from the surface to $<5 \mathrm{~cm}$ depth) during the bloom than at $5 \mathrm{~m}$, where the maximum of chlorophyll was located and they concluded that TEP were indeed moving upward. Since TEP in particular (Niven et al., 1997) and acid polysaccharides in general (Quigley et al., 2002) are known to be highly reactive with thorium, the hypothesis that a large fraction of TEP ascend in the water column is supported by the observed concomitant accumulation of Thorium-234 and TEP in the surface layer (Azetsu-Scott and Niven, 2005). The fact that carbohydrate represents a major component of the SML (Williams et al., 1986) further supports the hypothesis that positively buoyant TEP move upward and accumulate in the SML. Wurl and Holmes (2008) demonstrated that the SML in both oceanic and estuarine systems was significantly enriched in TEP characterized by a high concentration of sulfate half-ester groups compared to the underlying water. They suggested that amongst the enrichment processes of TEP in the SML, the ascension of aggregates controlled by variation of TEP stickiness may represent a significant pathway. In addition, they showed that the SML originating from estuarine samples contained a higher fraction of TEP than that collected from oceanic samples. Although $\mathrm{pH}$ was not mentioned in their study, estuaries are known to experience strong changes in $\mathrm{pH}$. While, other factors may explain such a difference in the composition of the SML between the two estuarine and oceanic systems, such a coincidence is rather interesting in the light of the present results. In addition, in upwelling systems, which are known to exhibit $\mathrm{pH}$ often lower than 8 , it has been shown that vertical fluxes were not directly correlated to the standing stock of suspended POC (Kiørboe et al., 1998). Therefore, one may hypothesize that the discrepancy observed in upwelling between the standing stock of 
suspended POC and the rate of vertical export may be related to $\mathrm{pH}$ variations and TEP-mediated retention of POC in the surface upper layer.

Although it would have been more appropriate to decrease the $\mathrm{pH}$ by increasing $p \mathrm{CO}_{2}$ to mimic the ocean's acidification, this approach would have implied bubbling, process known to alter: (i) the size distribution of particles by promoting surface coagulation, and (ii) the vertical repartition of TEP. Therefore, an acid-driven acidification was considered more appropriate to investigate the effect of acidification on aggregation efficiency. Aggregation was studied inside 2-L turbulence chambers, thus, containing about $56.4 \mathrm{mmol}$ of $\mathrm{SO}_{4}^{2-}$. The volume of $\mathrm{H}_{2} \mathrm{SO}_{4}(95 \%)$ added to the 2- $\mathrm{L}$ solutions to decrease the $\mathrm{pH}$ were $5.5 \mu \mathrm{L}, 8.9 \mu \mathrm{L}$ and $15.3 \mu \mathrm{L}$ for a diminution of $\mathrm{pH}$ of $0.2,0.4$, and 0.8 units, respectively. Acid was first diluted in $0.2-\mu \mathrm{m}$ filtered seawater $(1 \mathrm{ml}$ $\mathrm{H}_{2} \mathrm{SO}_{4}$ in $100 \mathrm{ml}$ seawater) before to be added in the 2- $\mathrm{L}$ solutions. The molarity of the $\mathrm{H}_{2} \mathrm{SO}_{4}$ used was $17.8 \mathrm{~mol} \mathrm{~L}^{-1}$. Seawater contains about $28.2 \mathrm{mmol} \mathrm{L}^{-1}$ of $\mathrm{SO}_{4}^{2-}$. Therefore, according to the volumes of acid added in seawater to reduce the $\mathrm{pH}$, the concentration of $\mathrm{SO}_{4}^{2-}$ increased by only $0.17 \%, 0.28 \%$ and $0.48 \%$, for a diminution of $\mathrm{pH}$ of $0.2,0.4$, and 0.8 units, respectively. As a result, alteration of alkalinity, cation concentration in seawater, as well as interaction of excess sulfate half-ester sulfate reactive groups of TEP was very minor and was thus ignored.

Assuming that the observed responses to a reduction in $\mathrm{pH}$ driven by acid addition apply at a more global scale to the future natural environment, the present study suggests that predictions about future atmospheric $\mathrm{CO}_{2}$ concentration may be underestimated, as they assume a constant drawdown by the ocean. The effect of ocean acidification on the biological pump can be crudely estimated assuming that: phytoplankton cells interact with TEP the same way the beads did and phytoplankton abundance is equivalent to that of beads (i.e., by replacing the beads by phytoplankton cells), vertical carbon flux is dominated by TEP-phytoplankton aggregates, phytoplankton density is around $1.30 \mathrm{~g} \mathrm{~cm}^{-3}$ (from 1.10 to $1.50 \mathrm{~g} \mathrm{~cm}^{-3}$; Azetsu-Scott and Johnson, 1992), TEP density (Azetsu-Scott and Passow, 2004) is ca. $0.84 \mathrm{~g} \mathrm{~cm}^{-3}$, and using volume:carbon conversion factors for TEP (Mari, 1999) and for phytoplankton cells (Strathmann, 1967). In such a scenario about half of organic carbon contained in TEP-phytoplankton aggregates should settle down under current $\mathrm{pH}$ conditions, while this downward flux of organic carbon should drop to $<10 \%$ and the upward flux should raise to $>90 \%$ after a diminution of seawater $\mathrm{pH}$ of 0.2 units or more (Fig. 5). This scenario should be considered cautiously for several reasons. First, marine aggregates are not solely composed of TEP and phytoplankton, and dense enclosures, such as clays, may significantly enhance their density. Second, while the latex beads are not sticky and, thus, reduce the interspecific stickiness between TEP and beads, the phytoplankton cells as well as many other marine particles are sticky. Therefore one may expect TEP to associate with more

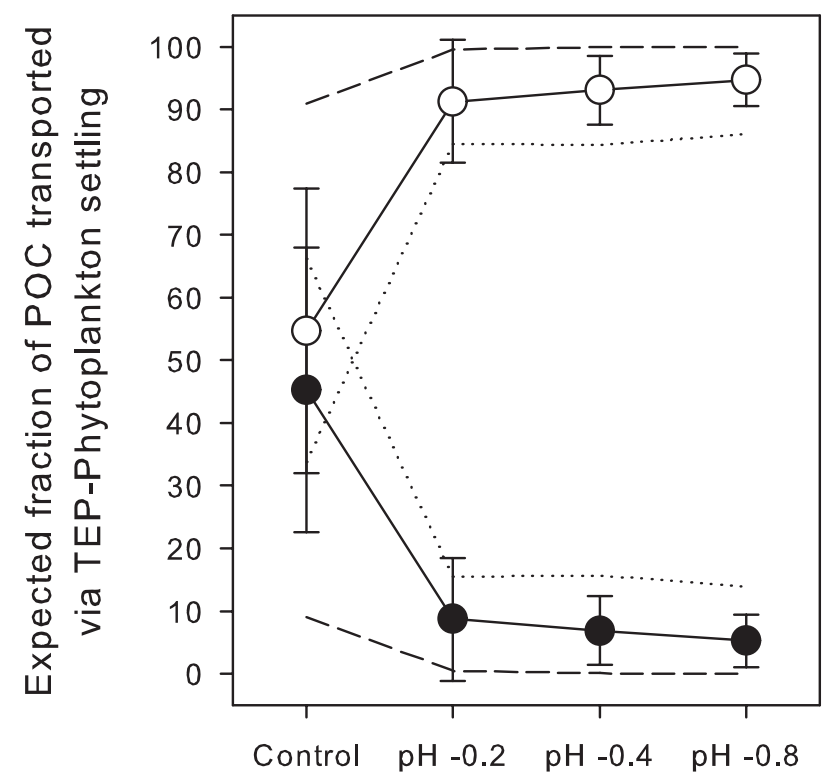

Fig. 5. Simplified model describing potential modifications of vertical transport of TEP-phytoplankton aggregates as a function of $\mathrm{pH}$. The expected fraction of particulate organic carbon (POC) transported upward (open circles) and downward (black circles) were estimated assuming an average density for phytoplankton of $1.30 \mathrm{~g} \mathrm{~cm}^{-3}$. The dotted and dashed lines represent the range of expected fraction POC transported considering the lower (i.e., $1.10 \mathrm{~g} \mathrm{~cm}^{-3}$ ) and higher (i.e., $1.50 \mathrm{~g} \mathrm{~cm}^{-3}$ ) limits for phytoplankton density, respectively.

naturally occurring particles than with latex beads. As a result, naturally occurring marine aggregates should be denser than extrapolated only from the interactions between TEP and beads. Finally, the sticking properties of TEP are quite variable (from ca. 0.1 to 0.8; Kiørboe and Hansen, 1993; Kiørboe et al., 1994; Dam and Drapeau, 1995; Logan et al., 1995; Engel, 2000; Mari and Robert 2008) and depend bloom dynamics (Dam and Drapeau, 1995; Engel, 2000) and environmental conditions (Mari and Robert, 2008) and, thus one may argue that the sensitivity of TEP to $\mathrm{pH}$ variations could vary as a function of bloom dynamics and environmental conditions.

\section{Conclusions}

As TEP have a density lower than seawater, the downward export of aggregates is possible if the contribution of dense particles to aggregates is high enough with regard to TEP contribution. The results allow concluding that a diminution of seawater $\mathrm{pH}$ induces a diminution of the sticking properties of TEP (as shown by the diminution of the number of attached beads per TEP) and an alteration of their structure, which translates in the apparition of larger swollen TEP. Both mechanisms concur to lessen the 
density of marine aggregates. Therefore, provided acidification driven by $\mathrm{H}_{2} \mathrm{SO}_{4}$ triggers similar mechanisms as acidification driven by $p \mathrm{CO}_{2}$, the acidification-induced inhibition of the downward flux of carbon and its counter part, the enhanced upward flux of material, may fuel the SML which ultimately should end up in the remineralization of organic carbon in the euphotic zone, hence, providing a positive feedback loop for the rising of atmospheric carbon and for climate change. Future work should not ignore the role of the SML in these processes.

Acknowledgements. I thank O. Pringault, E. Rochelle-Newall, J.-P. Torréton and M.G. Weinbauer for constructive comments and reviews on the developing manuscript, and P. Gerard for providing the nutrient data. This research was supported by the French National Research Agency (ANR-Blanc program: MAORY project).

Edited by: W. Kiessling

\section{References}

Alldredge, A. L., Passow, U., and Logan, B. E.: The abundance and significance of a class of large, transparent organic particles in the ocean, Deep-Sea Res., 40, 1131-1140, 1993.

Asper, V. L. W., Deuser, G., Knauer, G. A., and Lorenz, S. E.: Rapid coupling of sinking particle fluxes between surface and deep ocean waters, Nature, 357, 670-672, 1992.

Azetsu-Scott, K., and Johnson, B. D.: Measuring physical characteristics of particles: A new method of simultaneous measurement for size, settling velocity and density of constituent matter, Deep-Sea Res., 39, 1057-1066, 1992.

Azetsu-Scott, K. and Niven, S. E. H.: The role of transparent exopolymer particles (TEP) in the transport of Th-234 in coastal water during a spring bloom, Cont. Shelf Res., 25(9), 11331141, 2005.

Azetsu-Scott, K. and Passow, U.: Ascending marine particles: Significance of transparent exopolymer particles (TEP) in the upper ocean, Limnol. Oceanogr., 49, 741-748, 2004.

Boyd, P. W., Strzepek, R., Takeda, S., Jackson, G. A., Wong, C. S., McRay, R. M., Law, C., Kiyosawa, H., Saito, H., Sherry, N., Johnson, K., Gower, J., and Ramaiah, N.: The evolution and termination of an iron-induced mesoscale bloom in the northeast subarctic Pacific, Limnol. Oceanogr., 50, 1872-1886, 2005.

Caldeira, K. and Wickett, M. E.: Anthropogenic carbon and ocean pH, Nature, 425, 365-365, 2003.

Caldeira, K. and Wickett, M. E.: Ocean model predictions of chemistry changes from carbon dioxide emissions to the atmosphere and ocean, J. Geophys. Res., 110, C09S04, doi:10.1029/2004JC002671, 2005.

Dam, H. G. and Drapeau, D. T.: Coagulation efficiency, organicmatter glues and the dynamics of particles during a phytoplankton bloom in a mesocosm study, Deep-Sea Res. Part II, 42, 111123, 1995.

Dogsa, I., Kriechbaum, M., Stopar, D., and Laggner, P.: Structure of bacterial extracelullar polymeric substances at different $\mathrm{pH}$ values as determined by SAXS, Biophysical Journal, 89, 27112720, 2005.

Engel, A.: The role of transparent exopolymer particles (TEP) in the increase in apparent particle stickiness $(\alpha)$ during the decline of a diatom bloom, J. Plankton Res., 22, 485-497, 2000.

Engel, A.: Direct relationship between $\mathrm{CO}_{2}$ uptake and transparent exopolymer particles (TEP) in relation to their Alcian Blue adsorption, J. Plankton Res., 24, 49-53, 2002.

Engel, A. and Schartau, M.: Influence of transparent exopolymer particles (TEP) on sinking velocity of Nitzschia closterium aggregates, Mar. Ecol. Prog. Ser., 182, 69-76, 1999.

Engel, A., Thoms, S., Riebesell, U., Rochelle-Newall, E., and Zondervan, I.: Polysaccharide aggregation as a potential sink of marine dissolved organic carbon, Nature, 428, 929-932, 2004.

Feely, R. A., Sabine, C. L., Lee, K., Berelson, W., Kleypas, J., Fabry, V. J., and Millero, F. J.: Impact of anthropogenic $\mathrm{CO}_{2}$ on the $\mathrm{CaCO}_{3}$ system in the oceans, Science, 305, 362-366, 2004.

Fowler, S. W. and Knauer, G. A.: Role of large particles in the transport of elements and organic compounds through the oceanic water column, Prog. Oceanogr., 16, 147-194, 1986.

Gattuso, J.-P., Frankignoulle, M., Bourge, I., Romaine, S., and Buddemeier, R. W.: Effect of calcium carbonate saturation of seawater on coral calcification, Global Planet. Change, 18, 37-46, 1998.

Gazeau, F., Quiblier, C., Jansen, J. M., Gattuso, J.-P., Middelburg, J. J., and Heip, C. H. R.: Impact of elevated $\mathrm{CO}_{2}$ on shellfish calcification, Geophys. Res. Lett., 34, L07603, doi:10.1029/2006GL028554, 2007.

Jackson, G. A.: A model of the formation of marine algal flocs by physical coagulation processes, Deep-Sea Res., 37, 1197-1211, 1990.

Jackson, G. A. and Burd, A. B.: Aggregation in the marine environment, Environ. Sci. Tech., 32, 2805-2814, 1998.

Jackson, G. A., Waite, A. M., and Boyd, P. W.: Role of algal aggregation in vertical carbon export during SOIREE and in other low biomass environments, Geophys. Res. Lett., 32, L13607, doi:10.1029/2005GL023180, 2005.

Kiørboe, T. and Hansen, J. L. S.: Phytoplankton aggregate formation: observation of patterns and mechanisms of cell sticking and the significance of exopolymeric material, J. Plankton Res., 15, 993-1018, 1993.

Kiørboe, T., Landsgaard, C., Olesen, M., and Hansen, J. L. S.: Aggregation and sedimentation processes during a spring bloom: A field experiment to test coagulation theory, J. Mar. Res., 52, 297323, 1994.

Kiørboe, T., Tiselius, P., Mitchell-Innes, B., Hansen, J. L. S., Visser, A. W., and Mari, X.: Intensive aggregate formation with low vertical flux during an upwelling-induced diatom bloom, Limnol. Oceanogr., 43, 104-116, 1998.

Langdon, C., Broecker, W. S., Hammond, D. E., Glenn, E., Fitzsimmons, K., Nelson, S. G., Peng, T. H., Hajdas, I., and Bonani, G.: Effect of elevated $\mathrm{CO}_{2}$ on the community metabolism of an experimental coral reef, Glob. Biogeochem. Cycles, 17, 1011, doi:10.1029/2002GB001941, 2003.

Logan, B. E., Passow, U., Alldredge, A. L., Grossart, H.-P., and Simon, M.: Rapid formation and sedimentation of large aggregates is predictable from coagulation rates (half-lives) of transparent exopolymer particles (TEP), Deep-Sea Res. Part II, 42, 203-214, 1995. 
Mari, X.: Carbon content and C:N ratio of transparent exopolymeric particles (TEP) produced by bubbling exudates of diatoms, Mar. Ecol. Prog. Ser., 183, 59-71, 1999.

Mari, X., Rochelle-Newall, E., Torréton, J.-P., Pringault, O., Jouon, A., and Migon, C.: Water residence time: A regulatory factor of the DOM to POM transfer efficiency, Limnol. Oceanogr,. 52, 808-819, 2007.

Mari, X., and Robert, M.: Metal induced variations of TEP sticking properties in the southwestern lagoon of New Caledonia, Mar. Chem., 110, 98-108, doi:10.1016/j.marchem.2008.02.012, 2008.

Niven, S. H. E., Kepkay, P. E., and Bugden, J. B. C.: The role of TEP in ${ }^{234}$ Th scavenging during a coastal diatom bloom, Radioprotection, 32, 213-218, 1997.

Orr, J. C., Fabry, V. J., Aumont, O., Bopp, L., Doney, S. C., Feely, R., A., Gnanadesikan, A., Gruber, N., Ishida, A., Joos, F., Key, R. M., Lindsay, K., Maier-Reimer, E., Matear, R., Monfray, P., Mouchet, A., Najjar, R. G., Plattner, G. K., Rodgers, K. B., Sabine, C. L., Sarmiento, J. L., Schlitzer, R., Slater, R. D., Totterdell, I. J., Weirig, M. F., Yamanaka, Y., and Yool, A.: Anthropogenic ocean acidification over the twenty-first century and its impact on calcifying organisms, Nature, 437, 681-686, 2005.

Passow, U.: Transparent exopolymer particles (TEP) in aquatic environments, Prog. Oceanogr., 55, 287-333, 2002.

Passow, U., Shipe, R. F., Murray, A., Pak, D. K., Brzezinski, M. A., and Alldredge, A. L.: The origin of transparent exopolymer particles (TEP) and their role in the sedimentation of particulate matter, Cont. Shelf Res., 21, 327-346, 2001.

Peters, F., Marrase, C., Havskum, H., Rassoulzadegan, F., Dolan, J., Alcaraz, M., and Gasol, J. M.: Turbulence and the microbial food web: effects on bacterial losses to predation and on community structure, J. Plankton Res., 24, 321-331, 2002.

Quigley, M. S., Santschi, P. H., and Hung, C. C.: Importance of acid polysaccharides for ${ }^{234} \mathrm{Th}$ complexation to marine organic matter, Limnol. Oceanogr., 47, 367-377, 2002.

Richardson, T. L. and Jackson, G. A.: Small phytoplankton and carbon export from the surface ocean, Science, 315, 838-840, 2007.
Riebesell, U., Zondervan, I., Rost, B., Tortell, P. D., Zeebe, R. E., and Morel, F. M. M.: Reduced calcification in marine plankton in response to increased atmospheric $\mathrm{CO}_{2}$, Nature, 407, 364-367, 2000.

Riebesell, U., Schulz, K. G., Bellerby, R. G. J., Botros, M., Fritsche, P., Meyerhofer, M., Neill, C., Nondal, G., Oschlies, A., Wohlers, J., and Zollner, E.: Enhanced biological carbon consumption in a high $\mathrm{CO}_{2}$ ocean, Nature, 450, 545-548, 2007.

Sabine, C. L., Feely, R. A., Gruber, N., Key, R. M., Lee, K., Bullister, J. L., Wannikhof, R., Wong, C. S., Wallace, D. W. R., Tilbrook, B., Millero, F. J., Peng, T. H., Kozyr, A., Ono, T., and Rios, A. F.: The oceanic sink for anthropogenic $\mathrm{CO}_{2}$, Science, 305, 367-371, 2004.

Sarmiento, J. L. and Siegenthaler, U.: in: Primary Productivity and Biogeochemical Cycles in the Sea, edited by: Falkowski, P. G. and Woodhead, A. D., Plenum, New York, pp. 317-332, 1992.

Shanks, A. L. and Trend, J. D.: Marine snow, sinking rates and potential role in vertical flux, Deep-Sea Res., 27, 137-143, 1980.

Smetacek, V. S.: Role of sinking in diatom life-history cycles: Ecological, evolutionary, and geological significance, Mar. Biol., 84, 239-251, 1985.

Strathmann, R. R.: Estimating the organic carbon content of phytoplankton from cell volume or plasma volume, Limnol. Oceanogr., 12, 411-418, 1967.

Volk, T. and Hoffert, M. I.: Natural Variations Archean to Present. In: The Carbon Cycle and Atmospheric $\mathrm{CO}_{2}$. Sundquist, E. T., Broecker, W. S. (Eds.), AGU, Washington, 99-110, 1985.

Williams, P. M., Carlucci, A. F., Henrichs, S. M., Van Fleet, E. S., Horrigan, S. G., Reid, F. M. H., and Robertson, K. J.:Chemical and microbiological studies of sea-surface films in the Southern Gulf of California and off the West Coast of Baja California, Mar. Chem., 19, 17-98, 1986.

Wurl, O. and Holmes, M.: The gelatinous nature of sea-surface microlayer, Mar. Chem., 110, 89-97, 2008. 